|Volume 6 |Number 1 |May 2021 |E-ISSN: 2503-4405 |P-ISSN: 2580-3441 |

\title{
Pre-Service Teachers' Attitude toward Internet Use in Learning and Their Academic Achievement
}

\author{
Sulaiha1, Bambang A. Loeneto ${ }^{2}$, Dedi Kurniawan ${ }^{3}$ \\ 1,2,3English Education Department, Faculty of Teacher Training and Education, \\ Universitas Sriwijaya \\ 33dedikurniawan@unsri.ac.id
}

\begin{abstract}
The internet has helped us spreading knowledge in a very swift manner and to make its accessibility available for almost everyone. It can offer the possibility to help learners, with the right attitude, to achieve better in their respective fields. This study tries to investigate the attitude of pre-service teachers in an English Education Study Program in South Sumatra toward internet use in their teaching and learning process; and to check its relationship with their academic achievement. All active students, 157 in total, in an English Education Study Program in South Sumatra, Indonesia were taken in as the subjects of the study. The data were collected using Attitude toward Internet Use in Language Learning Questionnaire and students' cumulative GPA. The results revealed that most of the pre-service teachers showed a moderate level of positive attitude toward internet use $(77.71 \%, 21.02 \%$ for high level, $1.27 \%$ for low level) with affective aspect as the dominant factors for the attitude (followed by behaviour and cognitive aspects respectively). Furthermore, the results of the Pearson correlation indicated that there was a significant fair positive association between pre-service teachers' attitude toward internet use in learning and academic achievement, $(\mathrm{r}(157)=.443, \mathrm{p}=.001)$.This study also provided some implications and recommendations for further research.
\end{abstract}

Keywords:Attitude, Internet, Academic, Achievement.

\section{INTRODUCTION}

Internet is a medium for individuals with computers to collaborate and interact with others regardless of locales. It illustrates a very successful product of long-term contribution and engagement to information technology framework research and development (Leiner et al., 2009). From only for electronic mail communication, its utilization has expanded into every facet of life one of which is education. In this sector, it is extensively adopted for classroom activities in schools and universities. Jagboro (2003)argued that the internet has connected millions of computers around the globe. Additionally, thousands of corporations, government agencies, academic institutions, and educational institutions have adopted this technology. In line with this, Usun (2003) added that the use of the internet for educational purposes helps a lot and it is actually more efficient and effective for educational activities.

University students are native citizen of the internet as a generation born in the digital world era.D'Esposito \& Gardner (1999)state that if students have access to internet services, they choose to use it rather than libraries for their assignments. In line with this, Ezemenaka (2013)discovered that approximately 97 percent of students regularly used the internet to find different relevant knowledge for their schoolwork in his research on the effect of the internet on university students' academic focus. 
Furthermore, Siraj et al. (2015) discovered that 71.6 percent of 176 Malaysian Public University students used the internet to complete their assignments in a report on internet access and academic achievement.

In partnership with UNICEF, Kementrian Komunikasi dan Informasi (Indonesia Ministry of Communication and Information) (2014)determined that the internet can be an effective tool for teenagers to aid in their education, increase their skills, and broaden their opportunities for a better quality of life. However, the ministry's description contradicts the reality discovered by Heimerl et al. (2015). According to the findings of their research, majority of mobile users in remote areas of Indonesia mostly used the internet for texting rather than searching for education related specific information.

Academic achievement is one of the most important indicators determining student performance in a variety of subjects and areas (Shukakidze, 2013).As a result, academic success is the primary target of the higher education sector. Educators are constantly on the lookout for new approaches to improve instruction and attain optimal learning results (Eret et al., 2013). Internet, as has discussed before, offers a way to achieve better academic achievement. Students' attitude toward internet use in learning plays a role in achieving that and it needs further effort. Much attention has been paid to attitudes toward internet use as it is widely used to provide training to a diverse variety of students in order to attract and maintain them in institutions of higher education(Wiebe et al., 2002). In addition, Tuncer et al. (2013) discovered that optimistic views toward internet use improve success in learning experiences. Furthermore, Al Mahmud (2011) found that students had favorable attitudes toward using the internet as a learning platform, and that the attitude was associated with the increasing learning experience students engaged in.

Pre-service teachers nowadays are of no exception of the native citizen of the internet including the ones in this study. The results of the preliminary observation of the preservice students in this study (in an English Education Study Program in South Sumatra Province, Indonesia) revealed that the majority of them use the internet for daily activities as evidenced by their connection via social media, either for sharing information or for seeking academic related information. The internet related facility provided by the university all available almost in all buildings including classes and library. They can utilize the facilities for free. The uses include information searches and online discussion. Todays' pre-service teachers will work as teachers in $3-5$ years. They will face the $21^{\text {st }}$ learning challenges. It integrates literacy skills, knowledge skills, competence, and attitudes, as well as mastery of technology. It is an attempt to answer the challenges of the 21st century by mastering 21st century (Critical Thinking and Problem-Solving Skills, Communication Skills, Creativity and Innovation, and Collaboration) (Kemdikbud, 2017).

A similar study was done by Abdullah et al. (2015)involving 3534 university students at Koya University in Iraq. They compared attitude toward Information Technology (IT) between students in science and art departments. They also tried to find the relationship between the attitude and students' academic achievement. The results revealed that the students in science department had a higher score in relation to the attitude compared to those who in arts department. The findings have showed that there was no significant association between those two variables.

Sepahpanah et al. (2015)performed a related analysis with 269 Kermanshah Azad University students, investigating students' attitudes toward internet usage in education 
and attempting to determine their relationship with real internet use. The results showed that the students display a proper attitude toward the use of internet and the study also found out that there was no difference concerning the attitude between computer users and non-computer users. Furthermore, they also discovered that there was a significant association between the two variables.

In an experimental study (Kurniawan et al., 2020b) investigating the effect of collaboration through online collaboration tools on writing skills and mastery and also students' attitude toward the online learning activity. The study involved 48 pre-service English teachers which were divided into control and experimental groups. The results show that their writing skills mastery improved and they displayed a positive attitude toward the implementation of the online collaboration tools in learning.

In a qualitative study (Pitaloka et al., 2020)investigating 13 female and 5 male preservice English teachers' perception of blended learning program implementation. From the interview, they reported some advantages (flexible learning, challenging learning understandable materials, ease of use and variations in learning) and challenges (poor internet connection, limited time in reading exercises/quizzes, exact wordings for short answer test).

Most studies done on the topic of attitude toward internet use in learning did not focus their study in pre-service teachers. Instead, they investigated students in higher education in general. Focusing study relating to internet use in learning toward preservice teacher has its own importance. It will be beneficial if we have a deeper insight of their perception, such as attitude, advantages, challenges, etc. on internet use in learning. This information can help teacher educator to prepare the pre-service teacher for the upcoming challenges they will face as teachers. Furthermore, similar studies investigating pre-service teachers did not concentrate on the attitude toward the internet use in learning. The attitude was as the additional information reported in the studies. This study tried to address this gap by focusing on pre-service teachers and their attitude toward internet use in learning. As supplementary information, this study associated the attitude with the academic achievement which only few studies had done.

This present study, thus, investigated the attitude of pre-service teachers in an English Education Study Program in South Sumatra toward internet use in their teaching and learning process; and to check its relationship with their academic achievement in the study program. These aims are formulated in the research questions: (1) What is pre-service English teachers' attitude toward internet use in learning? (2) Is there any significant correlation between pre-service English teachers' attitude toward internet use in learning and their academic achievement?

\section{METHOD}

This is a correlational research in which two variables were explored, i.e. attitude toward internet use, the predictor variable; and academic achievement, the criterion variable. The Attitude toward Internet Use in Language Learning Questionnaire, adapted from Javad \& Leila (2015), was used to measure attitudes toward internet use. The questionnaire was split into two sections: (1) the first section included three questions about the students' frequency and content of internet use as background knowledge; and (2) the second section included 28 questions about attitude toward internet use in language learning. The attitude toward internet use questionnaire contains 40 items 
divided into three aspects: affective, behavioral, and cognitive. However, only 30 items were included in the study since the remaining ten questions were about teachers' attitudes. The questionnaire was tested on 35 non-sample students to determine its validity, and the findings were evaluated using corrected-item total correlation. The findings showed that 28 of the 30 items were valid (10 of affective aspect, 9 of behavior aspect, and 9 of cognitive aspect).The scale had five options: strongly agree, agree, neutral, disagree, and strongly disagree, with scores of 5, 4, 3, 2, and 1 respectively. Negative statements were graded in the inverse order. The Cronbach's Alpha for questionnaire reliability was.94. It indicated that it was highly reliable.

The academic achievement was taken from the documentation of the recent cumulative Grade Point Average (GPA) of the students which ranges from 0 to 4. The student's cumulative GPA is categorized into four predicates:unsatisfactory satisfactory (2.76-3.00), very satisfactory (3.01-3.50) and Cum-laude (3.51-4.00).

The samples were157 active students who are studying in an English Education Study Program in South Sumatra, Indonesia in the academic year 2019/2020.

The data were first summarized using means, standard deviation, minimum score, and maximum score. The GPA was categorized into 4 categories: unsatisfactory, satisfactory, very satisfactory, and cum-laude, while the attitude was into 3 levels: high, moderate, and low(Rajab et al., 2014). Pearson product moment correlation coefficient was used to test the relationship between the two variables, and it was then analyzed using interpretation table of Creswell (2012). Coefficient of determination ( $\mathrm{r}^{2}$ ) was used to see the contribution of the attitudes toward academic achievement. Before the data from the two variables were analyzed parametrically, they were checked for normality and homogeneity.

\section{RESULTS}

\section{Attitude toward Internet Use in Learning Questionnaire}

\section{a. Frequency and the Contents of Internet Use}

The questions asked for this part were: (1) How many hours do you use internet in a day? (2) What do you use the internet browse for? And (3) which of the following internet technologies do you consider indispensable? For question 1, 72 percent of 157 pre-service teachers used the internet more than 4 hours a day, 12 percent used it 3-4 hours a day, 8 percent used it 2-3 hours a day, 7 percent used it 1-2 hours a day, and only 1 percent used it less than 1 hour a day. They spent more than four hours a day on average accessing the internet. There were five choices for question 2 , and they could choose more than one: school, shopping/gathering product knowledge, entertainment, interacting with others, gathering information for personal purposes, and other. The results in order were as follows: communication $(81.3 \%)$, entertainment $(74.1 \%)$, gathering information for personal purposes $(71.5 \%)$ education $(68.9 \%)$ and shopping (45.6\%). For oftiom "other", they put games, reading online fiction book, religion, and sports as their personal options. They did a lot of activities on the internet. However, the most dominant were for communication and entertainment. For question 3, there are 5 options which can also can have multiple answers: search engine, email, chat/online discussion, Youtube, Instagram and "other". The results in order were: Search Engine (82.4\%), Chat/online discussion (78.8\%),Youtube (70.5\%), Instagran (56\%) and email (48.7\%). For option 'other' they put Twitter, Facebook, Line, Wattpad, games and Joox. 
The prevailing indispensable internet technologies were search engine and chat/online discussion.

\section{b. Attitude toward Internet Use in Learning}

The results showed that affective aspect has the highest score (6518) followed by behavior (5667) and cognitive (5640). Affective aspect affected the students the most of their attitude toward internet use in learning.

The affective aspects have ten items representing the feelings and emotions related to the object of the attitude. This is a physiological reaction to an individual or circumstance. As in the other two aspects, the answers were split into two poles: agreement (agree and strongly agree) and disagreement (disagree and strongly disagree).The pre-service teacher responded to item 9 'internet can provide non-native speakers of English with a rich learning environment' with the highest level of agreement $(95.55 \%$, strongly agree $(90.45 \%)$ or agree $(5.10 \%))$. It confirmed that they considered a rich learning experience to be one of the internet's greatest advantages. The distribution of answers is described in Table 1.

Behaviour aspects, in which 9 items were distributed, presented the intention to act on the object of attitude. It might take the form of goals, plans, and expectations regarding a particular person, organization, or object. Item 13 (Internet allows me to create materials that enhance my learning) in this part received the highest agreement response $(90.45 \%)$. This demonstrated that they saw the internet as one of the options for improving their learning materials.

The third one is the cognitive aspect, about which 9 questions were asked. The interpretation of one's reality, mental models (beliefs of cause and effect), and perceptions about subjects of attitude are all components of cognitive (belief).Cognitive is sometimes considered to be a part of reason and logical mindset. For this aspect, item 21 'in my belief, ESL/EFL websites are useful for learning English' has the highest agreement response (90.45\%). This meant that they regarded websites available on the internet as suitable for most students learning the English Language. Table 1 represented the distribution of responses to the three aspects.

Table 1 Questionnaire Response Distribution

\begin{tabular}{|c|c|c|c|c|c|c|}
\hline $\begin{array}{l}\mathrm{N} \\
\mathrm{o}\end{array}$ & Affective Aspects & $\begin{array}{l}\text { SA } \\
(\%)\end{array}$ & $\begin{array}{c}\text { A } \\
(\%)\end{array}$ & $\begin{array}{c}\mathrm{N} \\
(\%)\end{array}$ & $\begin{array}{c}\mathrm{D} \\
(\%)\end{array}$ & $\begin{array}{l}\text { SD } \\
(\%)\end{array}$ \\
\hline 1 & Information obtained from ESL/EFL websitesis useful & 38.88 & 54.78 & 5.73 & 0.64 & - \\
\hline 2 & I feel confident locating the information I need on the Internet for my learning & 19.11 & 66.88 & 12.74 & 0.64 & 0.64 \\
\hline 3 & The Internet has become an indispensable(necessary) tool in my learning. & 47.13 & 40.13 & 12.74 & - & - \\
\hline 4 & It is easy to locate useful information on the Internet & 26.74 & 59.25 & 12.74 & 1.27 & - \\
\hline 5 & $\begin{array}{l}\text { The Internet is always my first choice for research for finding new learning } \\
\text { strategies }\end{array}$ & 37.58 & 45.23 & 15.92 & 1.27 & - \\
\hline 6 & Internet is not useful for language learning. & 0.64 & 3.18 & 10.83 & 49.04 & 36.31 \\
\hline 7 & Internet has no place in theclassrooms & - & 1.27 & 11.46 & $\begin{array}{l}65.6 \\
1\end{array}$ & 21.66 \\
\hline 8 & Internet can be an effective learning way for students. & 26.75 & 62.43 & 9.55 & 1.27 & - \\
\hline 9 & $\begin{array}{l}\text { The Internet can provide non-native speakers of English with a rich learning } \\
\text { environment }\end{array}$ & 5.10 & 90.45 & 4.45 & - & - \\
\hline \multirow[t]{3}{*}{10} & $\begin{array}{l}\text { The Internet is a useful tool for helping me achieve my future learning } \\
\text { purpose. }\end{array}$ & 23.57 & 64.33 & 12.10 & - & - \\
\hline & Mean & 28.28 & 59.81 & 10.83 & 0.95 & 0.13 \\
\hline & Behavior Aspects & $\begin{array}{c}\text { SA } \\
(\%)\end{array}$ & $\begin{array}{c}\text { A } \\
(\%)\end{array}$ & $\begin{array}{c}\mathrm{N} \\
(\%)\end{array}$ & $\begin{array}{l}\mathrm{D} \\
(\%)\end{array}$ & $\begin{array}{l}\text { SD } \\
(\%)\end{array}$ \\
\hline
\end{tabular}




\begin{tabular}{|c|c|c|c|c|c|c|}
\hline 11 & $\begin{array}{l}\text { I think I would like to use Internet assisted language learning materials and } \\
\text { activities in my future EFL learning as much as possible }\end{array}$ & 21.02 & 64.97 & 13.38 & 0.64 & - \\
\hline 12 & $\begin{array}{l}\text { I canget more current information from the internet rather than from printed } \\
\text { materials for better learning }\end{array}$ & 22.93 & 58.60 & 15.29 & 3.18 & - \\
\hline 13 & Internet allows me to create materials that enhance my learning. & 19.11 & 71.34 & 8.92 & 0.64 & - \\
\hline 14 & Using the Internet could speed up my learning & 21.66 & 63.06 & 14.65 & 0.64 & - \\
\hline 15 & Time spent on the Internet is worthwhile for learning & 12.10 & 59.87 & 22.93 & 5.10 & - \\
\hline 16 & I find using the Internet as an integral part of the educational process & 13.38 & 71.34 & 14.65 & 0.64 & - \\
\hline 17 & Using internet for learning is a priority for me & 17.20 & 54.14 & 22.93 & 5.73 & - \\
\hline 18 & Using Internet makes the subject matter more interesting & 29.30 & 53.50 & 14.01 & 3.18 & - \\
\hline \multirow[t]{3}{*}{19} & Internet improves education & 33.12 & 55.41 & 9.55 & 1.27 & 0.64 \\
\hline & Mean & 21.09 & 61.36 & 15.15 & 2.34 & 0.07 \\
\hline & Cognitive Aspects & $\begin{array}{c}\text { SA } \\
(\%)\end{array}$ & $\begin{array}{c}\text { A } \\
(\%)\end{array}$ & $\begin{array}{c}\mathrm{N} \\
(\%)\end{array}$ & $\begin{array}{c}\mathrm{D} \\
(\%)\end{array}$ & $\begin{array}{l}\text { SD } \\
(\%)\end{array}$ \\
\hline 20 & In my belief,Internet resources can replace text books & 17.83 & 41.40 & 28.03 & 12.74 & - \\
\hline 21 & In my belief,ESL/EFLwebsites are useful for learning English & 23.57 & 66.88 & 8.92 & 0.64 & - \\
\hline 22 & I think I am competent to useInternet-based materials in my future learning & 11.46 & 68.15 & 19.11 & 1.27 & - \\
\hline 23 & $\begin{array}{l}\text { I think I have to further learn how to integrate internet resources in to my } \\
\text { future learning }\end{array}$ & 23.57 & 64.97 & 10.83 & 0.64 & - \\
\hline 24 & In my belief, it is easy to find learning ESL/EFL materials on the Web & 27.40 & 57.32 & 14.01 & 1.27 & - \\
\hline 25 & $\begin{array}{l}\text { Through my learning experiences, I was motivated to learn English by the use } \\
\text { of the Internet. }\end{array}$ & 25.48 & 60.51 & 12.74 & 1.27 & - \\
\hline 26 & $\begin{array}{l}\text { Through my learning experiences, I improved English skills through the use of } \\
\text { the Internet }\end{array}$ & 22.93 & 66.88 & 9.55 & 0.64 & - \\
\hline 27 & $\begin{array}{l}\text { Through my learning experiences, Internet resources provided me more } \\
\text { opportunities for autonomous learning }\end{array}$ & 20.38 & 64.33 & 14.65 & - & 0.64 \\
\hline \multirow[t]{2}{*}{28} & $\begin{array}{l}\text { Through my learning experiences, I improved my communication skills by e- } \\
\text { mailing or chatting with native speakers of English on-line. }\end{array}$ & 15.29 & 53.50 & 24.20 & 6.37 & 0.64 \\
\hline & Mean & 19.96 & 61.50 & 15.64 & 2.69 & 0.21 \\
\hline
\end{tabular}

The results of the analysis showed that the pre-service teacher attitude toward internet use in language learning was in moderate level $(M=113.54, S D=8.80, M a x=138$, Min=100). When pre-services teachers in each semester were compared, the highest results were from semester $8(\mathrm{~N}=37, \mathrm{M}=119.32, \mathrm{SD}=10.19 \mathrm{Max}=138 \mathrm{Min}=103)$, followed by semester $6(\mathrm{~N}=37, \mathrm{M}=112.95, \mathrm{SD}=7.54 \mathrm{Max}=131 \mathrm{Min}=102)$, semester $4(\mathrm{~N}=35$, $\mathrm{M}=112.09, \mathrm{SD}=7.63 \mathrm{Max}=135 \mathrm{Min}=104)$ and semester $2(\mathrm{~N}=48, \mathrm{M}=110.58, \mathrm{SD}=7.39$ Max=128 Min=100) respectively., Table 2 display the complete distribution of the attitude levels while table 3 shows the comparison of results in each semester.

Table 2 Attitude Level Distribution

\begin{tabular}{llccc}
\hline No. & $\begin{array}{l}\text { Level of Attitude } \\
\text { towardInternet }\end{array}$ & Interval & Frequency & Percentage \\
\hline 1 & High & $121-140$ & 33 & $21.02 \%$ \\
2 & Moderate & $101-120$ & 122 & $77.71 \%$ \\
3 & Low & $80-100$ & 2 & $1.27 \%$ \\
\hline & & & 157 & $100 \%$
\end{tabular}

The result show that it was in moderate level which means most students had a positive attitude toward internet use. Affective aspect has the most positive response as compared to the other two aspects which shows that the feeling of comforts was their main reason for using internet.

\section{Students' Cumulative Grade Point Average}

The results show that the GPA was divided into four categories: unsatisfactory (6\%), satisfactory (13\%), very satisfactory (61\%), and cumlaude (20\%). The GPA distribution was divided into each semester: semester $8(M=3.38 \mathrm{SD}=0.24, \mathrm{Max}=3.90, \mathrm{Min}=2.76)$, semester $6(M=3.29 \mathrm{SD}=0.34, \mathrm{Max}=3.92$, $\mathrm{Min}=2.35)$, semester $4(\mathrm{M}=3.30 \mathrm{SD}=0.23$, 
Max=3.83, Min=2.84), and semester $2(\mathrm{M}=3.16 \mathrm{SD}=0.42$, $\mathrm{Max}=3.92, \mathrm{Min}=1.42)$. For the whole data, the GPA mean was 3.27 ( $\mathrm{SD}=0.33, \mathrm{Max}=3.92$, Min=1.42). The score distribution based on semester is shown in table 3 .

Table 3 GPA Distribution

\begin{tabular}{cccccc}
\hline Semester & N & Minimum & Maximum & Mean & Std. Deviation \\
\hline 2 & 48 & 1.42 & 3.92 & 3.16 & .42 \\
4 & 35 & 2.84 & 3.83 & 3.30 & .23 \\
6 & 38 & 2.35 & 3.92 & 3.29 & .34 \\
8 & 36 & 2.76 & 3.90 & 3.38 & .24 \\
\hline Total & 157 & 1.42 & 3.92 & 3.27 & 0.33 \\
\hline
\end{tabular}

\section{Normality and Homogeneity Tests}

The result of Kolmogorov-Smirnov tests for the Attitude and GPA are described in table 4.

Table 4 Normal Distribution Test

\begin{tabular}{cccc}
\hline & & \multicolumn{2}{c}{ Kolmogorov-Smirnov } \\
& Statistic & Df & Sig. \\
\hline Questionnaire & .097 & 157 & .002 \\
GPA & .066 & 157 & .580 \\
\hline
\end{tabular}

A Kolmogorov-Smirnov test results showed that the response for the questionnaire do not follow a normal distribution, $\mathrm{D}(157)=0.097, \mathrm{p}=0.002$. While the same test for GPA indicates that it follows a normal distribution, $\mathrm{D}(157)=0.066, \mathrm{p}=0580$. Since the sample number is higher than 30 , the results can be ignored and the distributions are considered normal.

The result of Levene's tests for Attitude toward Internet in Language Learning and GPA are described in table 5.

Table 5 Homogeneity Test

\begin{tabular}{cccc}
\hline $\begin{array}{c}\text { LeveneS } \\
\text { tatistic }\end{array}$ & df1 & df2 & Sig. \\
\hline 1.453 & 32 & 113 & .079 \\
\hline
\end{tabular}

Levene's test showed that the variances for Attitude toward Internet in Language Learning and GPA were equal, $\mathrm{F}(32,113)=1.453, \mathrm{p}=0.079$, that is both data were homogenous. 


\section{The Result of Correlation Analysis between Attitude toward Internet Use and Academic Achievement}

Pearson product moment correlation coefficient analysis for both variables is described in table 6.

Table 6 the Correlation between Attitude toward Internet Use and Academic Achievement

\begin{tabular}{llll}
\hline \multicolumn{4}{c}{ Correlations } \\
& & Attitude & GPA \\
\hline \multirow{4}{*}{ Attitude } & PearsonCorrelation & 1 & $.443^{* *}$ \\
& Sig.(2-tailed) & & .001 \\
& $\mathrm{~N}$ & 157 & 157 \\
& PearsonCorrelation & $.443^{* *}$ & 1 \\
GPA & Sig.(2-tailed) & .001 & \\
& $\mathrm{~N}$ & 157 & 157 \\
\hline
\end{tabular}

Among the research samples in the Study Program, their attitude and academic achievement were significantly correlated in positive direction, $r(157)=.44, p<.001$. The strength of the association between the variables wasfair(Cresswell, 2012).

For each aspect of the attitude toward internet use, its association toward academic achievement is described in table 7.

Table 7 The Correlation among each Aspect

\begin{tabular}{ccc}
\hline Attitude & r-obtained & $\begin{array}{c}\text { p-value } \\
\text { Sig (2-tailed) }\end{array}$ \\
\hline Affective & .559 & .001 \\
Behavior & .279 & .001 \\
Cognitive & .210 & .008 \\
\hline
\end{tabular}

The correlation between each aspect and academic achievement was all positive and significant with affective aspect having the strongest association (.559), followed by behavior (.279) and cognitive (.210) respectively.

Coefficient of determination $\left(\mathrm{r}^{2}\right)$ shows how much the pre-service teacher attitude toward internet use in learning contributed to the academic achievement, which was .2. This statistic demonstrated $20 \%$ of the difference in students' academic achievements was explained by their attitude toward Internet use.

\section{DISCUSSION}

Considering the results above, the three questions in the first part of the questionnaire indicated that most subjects used the internet for more than four hours a day, seven days a week, which suggests they spent most of their time surfing the internet.Therefore, it was clearthat they use internet for spending their spare time. The three websites which they considered as the most important ones were search engine, chat, or online discussion and YouTube. These were used for communicating, finding information and entertainment. Apart from that, more than half of the pre-service 
teachers use it for educational purposes more intensively compared to the rest of them. Furthermore, while the internet is not their first choice for searching facts, it can also be a viable alternative when other problems arise.

These findings are consistent with the findings of Acut et al. (2016)who discovered that most students used the internet for social networking and academic purposes (second highest after social networking). Just 54\% of 386 respondents said they still use the internet for scholarly purposes. However, among the other reasons for using the internet, only academic motives have a noticeable impact on respondents' GPA.In line with this, Dogruer et al. (2011)discovered that 65 percent of their respondents use the internet for contact, which is consistent with this. While it is used for correspondence, the majority of students use it for subject and homework.

The results of the second part questionnaire revealed varied results. Items in affective aspects were dominantly responded in a positive direction. That the pre-service teachers view a rich learning environment as one of the benefits provided on internet was with the same theme as with what Howe (2016)concluded that IT facility including internet was the most successful models for learning. The internet has aided students in becoming more engaged in their learning, especially language learners. The highlight in behavior aspect was that internet had made possible for pre-service teachers to enhance their learning material. The results might be connected to the fact that internet has provided a rich learning environment.Lee (2000) in a similar tone inferred that internet can provide many authentic teaching-learning materials. The findings in cognitive aspect featured that websites were useful for learning English. This seems a natural situation when we connect the features of other aspects with this one: rich learning environment which enhances learning material results in useful learning process. Similar to this is what Kurniawan et al. (2020) deduced in his experiment that the use of internet facility (cloud technology) has given a positive impact toward pre-service teachers' attitude toward learning, and even more it actually can improved ones' language mastery ((Kurniawan et al., 2020a), (Medoukali, 2015), (Alqahtani, 2014)) . Furthermore, lengths of study seem to have some effect in the preservice teachers' attitude as shown in the results that higher semesters showed a more positive attitude as compared to the lower ones. Renschler et al. (2016) in their study on attitude found varied results of its association with length of program, one group showed effect of time toward attitude while others showed no effect at all.

The correlational analysis showed that the more positive pre-service teachers' attitude toward internet use in the higher the academic achievement they achieved. Furthermore, contribution of the attitude toward academic achievement is significant explaining almost one fifth of the variance in the academic achievement.Slameto (1995) elaborates on students' academic success in general are influenced by internal and external factors. Internal factors include physical, psychological and exhaustion, while external factors include family, education, and community.Furthermore, Bertolini et al. (2012) discovered that four variables influence achievement: macro-system (environmental conditions), micro-system (personality), exo-system (interaction with cultures in general), and meso-system (interaction with friends, teachers, and parents).

\section{CONCLUSION}

The pre-service teachers displayed a positive attitude toward internet use in learning, with a more positive attitudein higher semester students as compared to the lower ones. 
Affective aspect contributed the most toward the attitude, followed by behavior and cognitive aspect respectively. The positive significant association between attitude toward internet use in learning and academic achievement shows the potential of the attitude to contribute ones' success in learning process.

The results suggest that attitude toward internet use in learning should be considered by authorities when making decision or policies concerning facilities in education. Apart from that, future study can dig deeper in how each aspect in the attitude affects the attitude itself. Investigating the attitude association with other variables, such as motivation and self-efficacy can give us more comprehensive insight of its potential effects in education.

\section{ACKNOWLEDGMENT}

We are deeply indebted to all reviewers and editors for accepting our manuscript

\section{REFERENCES}

Abdullah, Z. D., Ziden, A. B. A., Aman, R. B. C., \& Mustafa, K. I. (2015). Students ' Attitudes towards Information Technology and the Relationship with their Academic Achievement. Contemporary Education Technology, 6(4), 338-354.

Acut, D. P., Carpo, M. J. C., Caparoso, J. K. V., Magsayo, J. R., \& Sombilon, V. A. (2016). Relationship of Students' Internet Usage and Academic Performance. The 4th International Conference of Science Educators and Teachers, 2-9.

Alqahtani, E. T. (2014). Effectiveness of Using YouTube on Enhancing EFL Students' Listening Comprehension Skills [Al-Imam Muhammad Ibin Saud Islamic University]. https://www.awej.org/images/Theseanddissertation/EbtissamAlqahtani/ebtissam alqahtanifullthesis.pdf

Bertolini, K., Stremmel, A., \& Thorngren, J. (2012). Student Achievement Factors. http://files.eric.ed.gov/fulltext/ED568687.pdf

Creswell, J. W. (2012). Educational research: Planning, conducting, and evaluating quantitative and qualitative research (4th ed.). Pearson Education, Inc.

D’Esposito, J. E., \& Gardner, R. M. (1999). University Students' Perceptions of the Internet: An Exploratory Study. Journal of Academic Librarianship, 25(6), 456-461.

Dogruer, N., Eyyam, R., \& Menevis, I. (2011). The use of the internet for educational purposes. Procedia - Social and Behavioral Sciences, 28, 606-611. https://doi.org/10.1016/j.sbspro.2011.11.115

Eret, E., Gokmenoglu, T., \& Demir, C. (2013). A Review of Research on Educational Theories and Approaches Affecting A Review of Research on Educational Theories and Approaches Affecting Students Achievement: 1990-2011. Elementary Education Online, 12(3), 687-700.

Ezemenaka, K. E. (2013). The usage and impact of Internet enabled phones on academic concentration among students of tertiary institutions : A study at the The usage and impact of Internet enabled phones on academic concentration among students of tertiary institutions: A study. The International Journal of Education and Development Using Information and Communication Technology, 9(3), 162-173.

Heimerl, K., Ali, K., Menon, A., Brewer, E., Hasan, S., \& Parikh, T. (2015). Analysis of Smartphone Adoption and Usage in a Rural Community Cellular Network. The Seventh International Conference on Information and Communication Technologies 
and Development - ICTD, 1-4. https://doi.org/10.1145/2737856.2737880

Howe, W. (2016). A Brief History of the Internet: An anecdotal history of the people and communities that brought about the Internet and the Web. Internet Article.

Jagboro, K. (2003). A study of Internet usage in Nigerian universities: A case study of Obafemi Awolowo University, Ile-Ife, Nigeria. First Monday, 8(2). https://doi.org/10.5210/fm.v8i2.1033

Javad, K. H., \& Leila, A. A. (2015). Attitudes toward using the Internet for language learning: A case of Iranian English teachers and learners. International Journal of Research Studies in Educational Technology, 4(1), 63-78. https://doi.org/10.5861/ijrset.2015.1029

Kemdikbud. (2017). Panduan Implementasi Keterampilan Abad 21 Kurikulum 2013 di SMA. Kementerian Pendidikan dan Kebudayaan.

Kementrian Komunikasi dan Informasi. (2014). Riset Kominfo dan UNICEF Mengenai Perilaku Anak dan Remaja Dalam Menggunakan Internet. Press Release. https://kominfo.go.id/content/detail/3834/siaran-pers-no-17pihkominfo22014tentang-riset-kominfo-dan-unicef-mengenai-perilaku-anak-dan-remaja-dalammenggunakan-internet/0/siaran_pers

Kurniawan, D., Suganda, L. A., \& Zuraida. (2020a). Cloud Collaborative Reflective Strategy and Its Effect Toward English Pronunciation of Pre-Service Teachers in Their Teaching Practice Program. International Conference on Progressive Education (ICOPE 2019), 422, 141-146. https://doi.org/10.2991/assehr.k.200323.107

Kurniawan, D., Suganda, L. A., \& Zuraida, Z. (2020b). Cloud Collaboration: Its Effect toward Writing Achievement and Impact toward Attitude to Learning. 4(2), 466-482.

Lee, K. (2000). English Teachers' Barriers to the Use of Computer-assisted Language Learning. The Internet TESL Journal, 6(12). http://iteslj.org/Articles/LeeCALLbarriers.html

Leiner, B. M., Clark, D. D., Kahn, R. E., Kleinrock, L., Lynch, D. C., Postel, J., Roberts, L. G., \& Wolff, S. (2009). A Brief History of the Internet Professor of Computer Science. ACM SIGCOMM Computer Communication Review, 39(5), 22-31. https://doi.org/10.1145/1629607.1629613

Medoukali, F. (2015). Developing EFL L earners ' Listening Comprehension through YouTube Videos [Mohamed Kheider University]. http://archives.univbiskra.dz/bitstream/123456789/5806/1/Farid MEDOUKALI.pdf

Pitaloka, N. L., Anggraini, H. W., Kurniawan, D., Erlina, E., \& Jaya, H. P. (2020). Blended Learning in a Reading Course: Undergraduate EFL Students 'Perceptions and Experiences. 4(1), 43-57.

Rajab, A., Wahab, S. R. A., Shaari, R., Panatik, S. A., \& Nor, F. M. (2014). Academic and Social Adjustment of International Undergraduates: A Quantitative Approach. 2(4), 5-8. https://doi.org/10.7763/JOEBM.2014.V2.133

Renschler, L., Rhodes, D., \& Cox, C. (2016). Effect of interprofessional clinical education programme length on students' attitudes towards teamwork. Journal of Interprofessional Care, 30(3), 338-346. https://doi.org/10.3109/13561820.2016.1144582

Sepahpanah, M., Movahedi, R., \& Farani, A. Y. (2015). The Study of Students' Attitudes towards the Use of Internet in Education (Case Study: Kermanshah Azad University). Interdisciplinary Journal of Virtual Learning in Medical Sciences, 6(3), 40-51.

Shukakidze, B. (2013). Comparative Study: Impact of Family, School, and Students Factors on Students Achievements in Reading in Developed (Estonia) and 
Developing (Azerbaijan) Countries. International Education Studies, 6(7), 131-143. https://doi.org/10.5539/ies.v6n7p131

Siraj, H. H., Salam, A., Hasan, N. A. bt, Jin, T. H., Roslan, R. B., \& Othman, M. N. Bin. (2015). Internet Usage and Academic Performance: A Study in a Malaysian Public University. International Medical Journal, 22(2), 83-86.

Slameto, S. (1995). Belajar dan Faktor-faktor yang Mempengaruhinya (B. Aksara (ed.)).

Usun, S. (2003). Undergraduate Students Attitudes towards Educational Uses of Internet. Interactive Educational Multimedia, 7, 46-62.

Wiebe, E. N., Shaver, E., \& Wogalter, M. S. (2002). Attitudes about the Internet: Implications for Use in Education. Journal of Education Technology System, 31(2), 143-156. https://doi.org/10.2190/L7UB-G81U-0MD5-3FK7 